\title{
THE EFFECT OF FERMENTATION METHOD, MICROBES INOCULATION AND CARBON SOURCE PROPORTION ON THE QUALITY OF ORGANIC FERTILIZER MADE FROM LIQUID WASTES OF CHICKEN SLAUGHTERHOUSE
}

\author{
Y. Sastro, B. Bakrie and N. R. Sudolar \\ Assessment Institute for Agricultural Technology of Jakarta Province, \\ Jl. Raya Ragunan No.30 Pasar Minggu, Jakarta 12540 - Indonesia \\ Corresponding E-mail: yudis_bkl2001@yahoo.com
}

Received October 03, 2013; Accepted November 28, 2013

\begin{abstract}
ABSTRAK
Penelitian ini bertujuan mengetahui pengaruh cara fermentasi, inokulasi mikroba, dan proporsi sumber karbon terhadap kualitas pupuk organik dari limbah cair yang diperoleh dari rumah pemotongan ayam di wilayah Jakarta. Perlakuan yang diuji adalah meliputi cara fermentasi, inokulasi mikroba dan proporsi sumber karbon. Pengamatan dilakukan setelah fermentasi berjalan selama tiga minggu, meliputi warna, aroma, kandungan unsur-unsur $\mathrm{C}, \mathrm{NH}_{4}, \mathrm{NO}_{3}$, total- $\mathrm{N}, \mathrm{P}_{2} \mathrm{O}_{5}, \mathrm{~K}_{2} \mathrm{O}$ dan kandungan mikroba pathogen (Fusarium sp., Coletotrichum sp., Salmonella sp., and Eschericia coli). Pupuk yang dihasilkan diujicobakan pada tanaman Caisin pada enam lokasi yang berbeda. Diperoleh hasil bahwa sistem fermentasi aerobik yang disertai inokulasi mikroba pengurai (Lactobacillus spp.) dan penambahan bahan sumber karbon sebanyak $20 \%$ (v/v) merupakan metoda fermentasi yang terbaik dalam menghasilkan pupuk organik cair yang dibuat dari limbah cair rumah pemotongan ayam. Namun demikian, respon tanaman Caisin terhadap pupuk hasil fermentasi nyata lebih rendah dibandingkan pupuk sejenis yang telah dikomersialkan (EM4). Kandungan nitrogen dan fosfor dari pupuk cair ini (92.000 ppm dan $143.000 \mathrm{ppm})$ nyata lebih tinggi $(\mathrm{P}<0.05)$ daripada kandungan pada EM4 (0,07 ppm dan 3,22 ppm).
\end{abstract}

Kata Kunci: Limbah cair, Fermentasi, Inokulasi, Karbon

\begin{abstract}
This study was to examine the effect of fermentation, inoculation, and the proportion of carbon sources on the quality of organic fertilizer made from fermentation of liquid waste collected from chicken slaughterhouse in Jakarta area. The parameters being tested included fermentation, microbial inoculation, and carbon source proportion. The observations were made after three weeks of fermentation on the color, odor, $\mathrm{pH}$, contents of elements $\mathrm{C}, \mathrm{NH}_{4}, \mathrm{NO}_{3}$, total- $\mathrm{N}, \mathrm{P}_{2} \mathrm{O}_{5}, \mathrm{~K}_{2} \mathrm{O}$ and pathogenic microbes (Fusarium sp., Coletotrichum sp., Salmonella sp. and Eschercia coli). The fertilizer were implemented for green chinese cabbage in six locations. It was found that the aerobic fermentation system combined with inoculation of the decomposer microbes (Lactobacillus spp.) and the addition $20 \%(\mathrm{v} / \mathrm{v})$ of a carbon source was the most appropriate method of fermentation in the production of liquid organic fertilizers from liquid waste of chicken slaughterhouse. The quality of the fertilizer which is based on physical, chemical and biological characteristics and crop responses still less than the similar commercial fertilizer (EM4). Nevertheless, the nitrogen and phosphor contents of this liquid fertilizer $(92,000 \mathrm{ppm}$ and $143,000 \mathrm{ppm})$ were significantly higher $(\mathrm{P}<0.05)$ than the EM4 $(0.07$ and $3.22 \mathrm{ppm})$.

Keywords: Liquid waste, Fermentation, Inoculation, Carbon
\end{abstract}

\section{INTRODUCTION}

The requirement for chicken meat in Jakarta area reached 600,000 heads per day. A total of 400,000 heads of which is collected and sold in
219 chicken pool and slaughtered in 1,153 chicken abattoir which are widely spread in and around Jakarta area. While the other 200,000 heads are slaughtered in the surrounding cities and it is transported to Jakarta either in fresh or 
frozen conditions. In addition to chicken meat, by products produced from chicken slaughterhouse are organic waste that often becomes a source of environmental pollution in urban areas.

The waste consists of solid waste such as dead chicken and feathers, as well as liquid wastes consisting of blood and waste water from washing process of the meats, gizzards and intestinal contents. The percentage of each waste reached $6.0-8.7 \%$ of the total live weight of the chicken (Arifin, 2004). Based on the assumption that the live weight of the chicken ready for slaughter is $1.8 \mathrm{~kg} /$ head (Adrizal, 2009), the total amount of waste generated from the chicken abattoir in Jakarta may reach 43.2 tons of solid waste and 63.0 tons of liquid waste per day.

The solid waste from chicken slaughterhouse, especially the feather, has generally been used by some people. Meanwhile, the liquid waste is generally directly discharged into the sewerage. Contrary to this fact, Tronina and Bubel (2008) and Okanovic et al. (2009) reported that the wastewater produced from poultry slaughterhouse containing $0.5-9.0 \%$ macro and micro nutrients, $11.0-15.2 \%$ organic carbon (C-organic), as well as $0.15-13.6 \%$ of amino acid substances. Likewise, the alimentary tracts which may contain up to $80 \%$ of total undigested substrates is a potential source to be utilized as organic fertilizers (Chojnacka et al., 2006; Kivela et al., 2009; Leon et al., 2009).

The use of liquid waste as organic fertilizer is constrained due to unavailability of appropriate technology to produce fertilizer that has good nutritive and aesthetics values. Liquid waste fermentation technology, as it has been reported by Borja et al. (2006), Kim (2011), and Sastro and Lestari (2011), is thought could be used to process liquid waste from the chicken slaughterhouses. However, there are problems in the characteristics of this liquid waste, as it is very much distinctive and different from the liquid waste that has been previously studied. These differences might lead to the differences in the performance of the fermentation process.

Therefore, researches related to the suitability of the material fermented with the fermentation factors, particularly the methods of fermentation, microbial inoculation, and the number of carbon source, still needs to be carried out. In relation to the above mentioned problems, an investigation has been conducted to examine the effect of fermentation, inoculation, and the number of carbon sources on the quality of organic fertilizer resulted from fermentation of liquid wastes collected from TPA in Jakarta area.

\section{MATERIALS AND METHODS}

\section{Materials}

The test for fermented fertilizer was conducted in the Integrated Laboratory and Greenhouse of the Assessment Institute for Agricultural Technology (BPTP) of Jakarta Province. The plant testing was carried out in vegetable farm owned by farmer in Ujung Menteng district, East Jakarta.

The materials used were molasses, liquid wastes collected from the First Collection Pond of chicken slaughterhouse in Rawa Kepiting, East Jakarta, and inoculum of Lactobacillus spp. with a density of $1 \times 10^{8}$ cell $\mathrm{ml}^{-1}$.

\section{Experimental Design and Treatments}

The trial was conducted using a $2 \times 2 \times 6$ factorial completely randomized design. Details of the treatment being tested included 1) fermentation, consisting of aerobic and anaerobic fermentation; 2) microbial inoculation, the treatments with or without inoculation using cultures of Lactobacillus spp., and 3) carbon source, addition of a carbon source (molasses) at the amount of $0,10,20,30,40$, and $50 \%$ of the volume of liquid waste. Thus, there were 24 treatment combinations in total and each combination was repeated five times.

The liquid waste was first mixed with the inoculum Lactobacillus spp. and with molasses in accordance with the treatment combination. A total of $250 \mathrm{ml}$ of those mixed materials were subsequently placed in a $500 \mathrm{ml}$ Erlenmeyer and tightly closed with thick plastic cover. While for the aerobic treatment, a total of 20 holes were made using a $1 \mathrm{~mm}$ size needle on the plastic cover of the Erlenmeyer.

\section{Parameters}

Observations were made after the materials were fermented for three weeks. Variables included in the observations were color, odor, contamination, $\mathrm{pH}$, contents of elements $\mathrm{C}, \mathrm{NH}_{4}$, $\mathrm{NO}_{3}$, total- $\mathrm{N}, \mathrm{P}_{2} \mathrm{O}_{5}, \mathrm{~K}_{2} \mathrm{O}$ and pathogenic microbes (Fusarium sp., Coletotrichum sp., Salmonella sp., and Eschericia coli).

\section{Plant Testing}

The plant testing conducted in farmers' fields involving six farmers as cooperators. The test 
plants used were the green chinese cabbage produced by East West Seed Company. The tested treatment consisted of a) liquid organic fertilizer made of fermented liquid waste from chicken slaughterhouse, selected from previous laboratory tests, and b) commercial liquid organic fertilizer (EM4) for comparison. The experiment was conducted using a completely randomized block design (CRBD) with each farmer cooperators as a group test.

Prior to the testing, the planting beds were fertilized with chicken manure as a basic fertilizer with a dose of 5 tons per hectare. The basic fertilizer was mixed evenly on each seedbed planting with the size of $10 \mathrm{~m}$ length $\mathrm{x} 1.5 \mathrm{~m}$ width $\times 0.20 \mathrm{~m}$ height. After application of the basic fertilizer, the planting beds were sufficiently watered and incubated for a week. The Chinese cabbage was planted after the seedlings were three weeks old and the planting space used was $10 \mathrm{~cm} \times 20 \mathrm{~cm}$, elongated in the direction of the planting beds.

A total of $100 \mathrm{ml}$ of each tested fertilizers was first dissolved in 10 liters of water, and then sprinkled evenly to the $10 \mathrm{~m}^{2}$ of the planting bed. The fertilizers were applied at 1, 2, and 3 weeks after planting. Observations were made on sampling plots of $100 \mathrm{~cm} \times 100 \mathrm{~cm}$ in size at 7 , 14 , and 21 days after planting. The observed variables consisted of plant height, leaf number, and plant fresh weight at harvest.

\section{Data Analysis}

Data of nutrient contents were analyzed using analysis of variance (ANOVA) followed by Duncan's Multiple Range Test (DMRT) at 5\% level test. The color, odor, and biological contaminant were presented in qualitative terms.

\section{RESULTS AND DISCUSSION}

\section{Characteristics of Fertilizer}

Based on the research results, as presented in Table 1 , it is seen that the fermentation does not significantly affect the $\mathrm{pH}$ of the fermentation. However, it has influences on the nutrient contents of $\mathrm{C}, \mathrm{N}, \mathrm{P}$, and $\mathrm{K}$. There was a reduction in the nutrient content of the aerobic fermentation treatment. There was no statistically significant interaction $(\mathrm{P}>0.05)$ between the tested treatment factors on observed parameter of nutrient contents.

Table 1. Effect of Fermentation Method, Inoculation and Carbon Proportion on Chemical Characteristics of Fertilizer Made from Liquid Waste of Chicken Slaughterhouse

\begin{tabular}{ccccccccc}
\hline Treatments & $\mathrm{pH}$ & $\begin{array}{c}\mathrm{C}- \\
\text { organic }\end{array}$ & $\begin{array}{c}\mathrm{N}- \\
\text { organic }\end{array}$ & ${\mathrm{N}-\mathrm{NH}_{4}}$ & ${\mathrm{~N}-\mathrm{NO}_{3}}$ & $\mathrm{~N}-\mathrm{Total}$ & $\mathrm{P}_{2} \mathrm{O}_{5}$ & $\mathrm{~K}_{2} \mathrm{O}$ \\
\hline $\begin{array}{c}\text { Fermentation System : } \\
\text { Anaerobic }\end{array}$ & $4.54^{\mathrm{a}}$ & $15.82^{\mathrm{b}}$ & $0.58^{\mathrm{b}}$ & $0.26^{\mathrm{b}}$ & $0.02^{\mathrm{b}}$ & $0.87^{\mathrm{b}}$ & $0.12^{\mathrm{b}}$ & $0.05^{\mathrm{b}}$ \\
$\begin{array}{c}\text { Aerobic } \\
\text { Inoculation : }\end{array}$ & $4.55^{\mathrm{a}}$ & $5.93^{\mathrm{a}}$ & $0.04^{\mathrm{a}}$ & $0.03^{\mathrm{a}}$ & $0.00^{\mathrm{a}}$ & $0.07^{\mathrm{a}}$ & $0.03^{\mathrm{a}}$ & $0.02^{\mathrm{a}}$ \\
Without inoculation & $4.64^{\mathrm{a}}$ & $14.09^{\mathrm{a}}$ & $0.51^{\mathrm{a}}$ & $0.26^{\mathrm{a}}$ & $0.04^{\mathrm{a}}$ & $0.81^{\mathrm{a}}$ & $0.13^{\mathrm{a}}$ & $0.05^{\mathrm{a}}$ \\
With Inoculation & $4.47^{\mathrm{a}}$ & $13.30^{\mathrm{a}}$ & $0.55^{\mathrm{a}}$ & $0.28^{\mathrm{a}}$ & $0.03^{\mathrm{a}}$ & $0.85^{\mathrm{a}}$ & $0.13^{\mathrm{a}}$ & $0.06^{\mathrm{a}}$ \\
Carbon addition (\%): & & & & & & & & \\
0 & $7.36^{\mathrm{c}}$ & $6.91^{\mathrm{a}}$ & $0.33^{\mathrm{a}}$ & $0.84^{\mathrm{d}}$ & $0.10^{\mathrm{b}}$ & $1.27^{\mathrm{c}}$ & $0.17^{\mathrm{c}}$ & $0.08^{\mathrm{b}}$ \\
10 & $5.84^{\mathrm{b}}$ & $11.83^{\mathrm{b}}$ & $0.52^{\mathrm{b}}$ & $0.34^{\mathrm{b}}$ & $0.05^{\mathrm{ab}}$ & $0.91^{\mathrm{b}}$ & $0.15^{\mathrm{bc}}$ & $0.06^{\mathrm{ab}}$ \\
20 & $3.91^{\mathrm{a}}$ & $14.43^{\mathrm{b}}$ & $0.76^{\mathrm{c}}$ & $0.15^{\mathrm{b}}$ & $0.02^{\mathrm{a}}$ & $0.92^{\mathrm{b}}$ & $0.14^{\mathrm{bc}}$ & $0.06^{\mathrm{ab}}$ \\
30 & $3.75^{\mathrm{a}}$ & $15.33^{\mathrm{bc}}$ & $0.61^{\mathrm{bc}}$ & $0.12^{\mathrm{b}}$ & $0.02^{\mathrm{a}}$ & $0.75^{\mathrm{ab}}$ & $0.12^{\mathrm{b}}$ & $0.05^{\mathrm{ab}}$ \\
40 & $3.67^{\mathrm{a}}$ & $16.16^{\mathrm{bc}}$ & $0.51^{\mathrm{b}}$ & $0.09^{\mathrm{a}}$ & $0.01^{\mathrm{a}}$ & $0.61^{\mathrm{a}}$ & $0.10^{\mathrm{b}}$ & $0.04^{\mathrm{a}}$ \\
50 & $3.28^{\mathrm{a}}$ & $18.03^{\mathrm{c}}$ & $0.33^{\mathrm{a}}$ & $0.06^{\mathrm{a}}$ & $0.01^{\mathrm{a}}$ & $0.40^{\mathrm{a}}$ & $0.07^{\mathrm{a}}$ & $0.03^{\mathrm{a}}$ \\
\hline
\end{tabular}

Different superscripts in the same column shows significantly different $(\mathrm{P}<0.05)$ 
Table 2. Physical Characteristics of Organic Fertilizer Made from Liquid Wastes of Chicken Slaughterhouse

\begin{tabular}{|c|c|c|c|c|c|c|c|c|c|c|}
\hline System & Inoculation & $\begin{array}{c}\text { Sugar } \\
(\%)\end{array}$ & Odor & Color & E. coli & Salmonella & Fus. & Phyt. & Colet. & Caterpillar \\
\hline Anaerobic & $\begin{array}{l}\text { Without } \\
\text { Inoculation }\end{array}$ & 0 & Stink & brownish & $1 \times 10^{4}$ & $2 \times 10^{5}$ & negative & negative & negative & none \\
\hline Anaerobic & $\begin{array}{l}\text { Without } \\
\text { Inoculation }\end{array}$ & 10 & Stink & brownish & $1 \times 10^{4}$ & $2 \times 10^{4}$ & negative & negative & negative & none \\
\hline Anaerobic & $\begin{array}{l}\text { Without } \\
\text { Inoculation }\end{array}$ & 20 & $\begin{array}{l}\text { Nice } \\
\text { smell }\end{array}$ & $\begin{array}{l}\text { darked } \\
\text { brown }\end{array}$ & Negative & Negative & negative & negative & negative & none \\
\hline Anaerobic & $\begin{array}{l}\text { Without } \\
\text { Inoculation }\end{array}$ & 30 & $\begin{array}{l}\text { Nice } \\
\text { smell }\end{array}$ & $\begin{array}{l}\text { darked } \\
\text { brown }\end{array}$ & Negative & Negative & negative & negative & negative & none \\
\hline Anaerobic & $\begin{array}{l}\text { Without } \\
\text { Inoculation }\end{array}$ & 40 & $\begin{array}{l}\text { Nice } \\
\text { smell }\end{array}$ & $\begin{array}{l}\text { brown } \\
\text { white }\end{array}$ & Negative & Negative & negative & negative & negative & none \\
\hline Anaerobic & $\begin{array}{l}\text { Without } \\
\text { Inoculation }\end{array}$ & 50 & $\begin{array}{l}\text { Nice } \\
\text { smell }\end{array}$ & $\begin{array}{l}\text { brown } \\
\text { white }\end{array}$ & Negative & Negative & negative & negative & negative & none \\
\hline Anaerobic & $\begin{array}{l}\text { With } \\
\text { Inoculation }\end{array}$ & 0 & Stink & brownish & $1 \times 10^{3}$ & $1 \times 10^{2}$ & negative & negative & negative & none \\
\hline Anaerobic & $\begin{array}{l}\text { With } \\
\text { Inoculation }\end{array}$ & 10 & Stink & brownish & $1 \times 10^{3}$ & $1 \times 10^{3}$ & negative & negative & negative & none \\
\hline Anaerobic & $\begin{array}{l}\text { With } \\
\text { Inoculation }\end{array}$ & 20 & $\begin{array}{l}\text { Nice } \\
\text { smell }\end{array}$ & $\begin{array}{l}\text { darked } \\
\text { brown }\end{array}$ & Negative & Negative & negative & negative & negative & none \\
\hline Anaerobic & $\begin{array}{l}\text { With } \\
\text { Inoculation }\end{array}$ & 30 & $\begin{array}{l}\text { Nice } \\
\text { smell }\end{array}$ & $\begin{array}{l}\text { darked } \\
\text { brown }\end{array}$ & Negative & Negative & negative & negative & negative & none \\
\hline Anaerobic & $\begin{array}{l}\text { With } \\
\text { Inoculation }\end{array}$ & 40 & $\begin{array}{l}\text { Nice } \\
\text { smell }\end{array}$ & $\begin{array}{l}\text { brown } \\
\text { white }\end{array}$ & Negative & Negative & negative & negative & negative & none \\
\hline Anaerobic & $\begin{array}{l}\text { With } \\
\text { Inoculation }\end{array}$ & 50 & $\begin{array}{l}\text { Nice } \\
\text { smell }\end{array}$ & $\begin{array}{l}\text { brown } \\
\text { white }\end{array}$ & Negative & Negative & negative & negative & negative & none \\
\hline Aerobic & $\begin{array}{l}\text { Without } \\
\text { Inoculation }\end{array}$ & 0 & Stink & $\begin{array}{l}\text { brown } \\
\text { yellow }\end{array}$ & $2 \times 10^{4}$ & $1 \times 10^{4}$ & negative & negative & negative & exist \\
\hline Aerobic & $\begin{array}{l}\text { Without } \\
\text { Inoculation }\end{array}$ & 10 & Stink & $\begin{array}{l}\text { brown } \\
\text { yellow }\end{array}$ & $1 \times 10^{3}$ & $1 \times 10^{3}$ & negative & negative & negative & exist \\
\hline Aerobic & $\begin{array}{l}\text { Without } \\
\text { Inoculation }\end{array}$ & 20 & $\begin{array}{l}\text { Nice } \\
\text { smell }\end{array}$ & $\begin{array}{l}\text { milky } \\
\text { brown }\end{array}$ & Negative & Negative & negative & negative & negative & none \\
\hline Aerobic & $\begin{array}{l}\text { Without } \\
\text { Inoculation }\end{array}$ & 30 & $\begin{array}{l}\text { Nice } \\
\text { smell }\end{array}$ & $\begin{array}{l}\text { milky } \\
\text { brown }\end{array}$ & Negative & Negative & negative & negative & negative & none \\
\hline Aerobic & $\begin{array}{l}\text { Without } \\
\text { Inoculation }\end{array}$ & 40 & $\begin{array}{l}\text { Nice } \\
\text { smell }\end{array}$ & pinky & Negative & Negative & negative & negative & negative & none \\
\hline Aerobic & $\begin{array}{l}\text { Without } \\
\text { Inoculation }\end{array}$ & 50 & $\begin{array}{l}\text { Nice } \\
\text { smell }\end{array}$ & pinky & Negative & Negative & negative & negative & negative & none \\
\hline Aerobic & $\begin{array}{l}\text { With } \\
\text { Inoculation }\end{array}$ & 0 & Stink & $\begin{array}{l}\text { brown } \\
\text { yellow }\end{array}$ & $1 \times 10^{1}$ & $1 \times 10^{2}$ & negative & negative & negative & exist \\
\hline Aerobic & $\begin{array}{l}\text { With } \\
\text { Inoculation }\end{array}$ & 10 & Stink & $\begin{array}{l}\text { brown } \\
\text { yellow }\end{array}$ & Negative & Negative & negative & negative & negative & exist \\
\hline Aerobic & $\begin{array}{l}\text { With } \\
\text { Inoculation }\end{array}$ & 20 & $\begin{array}{l}\text { Nice } \\
\text { smell }\end{array}$ & $\begin{array}{l}\text { milky } \\
\text { brown }\end{array}$ & Negative & Negative & negative & negative & negative & none \\
\hline Aerobic & $\begin{array}{l}\text { With } \\
\text { Inoculation }\end{array}$ & 30 & $\begin{array}{l}\text { Nice } \\
\text { smell }\end{array}$ & $\begin{array}{l}\text { milky } \\
\text { brown }\end{array}$ & Negative & Negative & negative & negative & negative & none \\
\hline Aerobic & $\begin{array}{l}\text { With } \\
\text { Inoculation }\end{array}$ & 40 & $\begin{array}{l}\text { Nice } \\
\text { smell }\end{array}$ & pinky & Negative & Negative & negative & negative & negative & none \\
\hline Aerobic & $\begin{array}{l}\text { With } \\
\text { Inoculation }\end{array}$ & 50 & $\begin{array}{l}\text { Nice } \\
\text { smell }\end{array}$ & pinky & Negative & negative & negative & negative & negative & none \\
\hline
\end{tabular}


Decline in nutrient content were allegedly caused by the high rate of nutrient acquisition by microbial fermentation in line with increased activity. Hoorman and Islam (2010) have previously reported that there is a decrease in nutrient content material decomposes in line with the increase in microbial populations. In addition, the decrease in the amount of $\mathrm{N}$ contained in the fermentation also caused changes in the form elements into the gas fraction that out of the fermentation system. The tendency is similar to the results of studies that have been reported by Anastassiadis (2007).

Treatment of microbial inoculation of Lactobacillus spp. in the fermentation system does not significantly affect the $\mathrm{pH}$ value and nutrient content of fermentation. It thus proves that the native decomposer microbes (endogenous) contained in the waste are available in sufficient quantities so that it can work equally well with microbes which are added. Therefore, in this case guarantees on the existence of decomposers in fermentation systems may not be necessary. This result was in line with results reported by Tsai et al (2007) that there is no difference in the rate of decomposition of food waste treatment between with and without inoculation of decomposer microbes.

Increasing the number of carbon sources resulted in a linear increase of the $\mathrm{C}$ content in the fermentation. Meanwhile, a decrease in $\mathrm{pH}$ value and the nutrient contents of $\mathrm{N}, \mathrm{P}$, and $\mathrm{K}$ in the fermented materials along with the addition of the carbon source (Table 1). Decrease in $\mathrm{pH}$ due to the addition of a carbon source associated with the production of organic acids by decomposer microbes is the same as in the report by Ali et al. (2002), Prado et al. (2005), Sastro et al. (2006), Karthikeyan and Sivakumar (2010), and Bonsmira and Jiang (2011) that there is an increased in production of organic acids, such as citric acid, lactic, and malic in the fermentation accompanied by the carbon source. Meanwhile, the decline in the number of nutrients fermented related to the increased in microbial activity in the decomposition, followed by an increase in the acquisition of nutrients by microbes, as it has also been reported by Nakasaki et al. (2005) and Cusack et al. (2011).

The distinctive smell of fermentation in the fermentation effluent was not affected by the fermentation method and inoculation treatments. Nevertheless, the power of a typical fermentation odor is influenced by granting carbon treatment. Distinctive odor of fermentation is due to the carbon additions to the treatment of $20 \%$ (v/v) and an increase in the power of a typical fermentation odor consistent to the increase in the number of carbon sources. Fermentation also affects the color of the fermentation. In addition, the fermentation system of the aerobic fermentation was tainted by caterpillars. This was not found in the treatment of anaerobic fermentation system (Table 2).

Biological contaminants in fermented materials were influenced by the amount of carbon that is included. Inclusion of carbon sources provide less than $10 \%$ chance of developing organisms polluters, both Caterpillar and pathogenic microbes (Eschericia coli and Salmonella sp.). There was no biological contamination in the treatment of carbon source addition of above $20 \%(\mathrm{v} / \mathrm{v})$. It was thought to be related to an increased in microbial activity and a decrease in $\mathrm{pH}$ of fermentation. The assumption was consistent with results reported by Coleman et al. (2003) and Burkepile et al. (2006). Meanwhile, soil-borne pathogens (soil borne diseases such as Fusarium sp., Coletotricum sp., and Phytium sp. were not found in any combination of the assessments conducted (Table 2). It thus thought to be related to the source of

Table 3. Growth and Production of Ghreen Chinese Cabbage Given Liquid Organic Fertilizer Made from Liquid Waste of Chicken Slaughterhouse Compared to Comparable Fertilizer

\begin{tabular}{|c|c|c|c|c|c|c|c|}
\hline \multirow{2}{*}{ Treatment } & \multicolumn{3}{|c|}{ Crop Height $(\mathrm{cm})$} & \multicolumn{3}{|c|}{ Leaf Numbers } & \multirow{2}{*}{$\begin{array}{c}\text { Fresh } \\
\text { Weight }(\mathrm{g})\end{array}$} \\
\hline & 7 HST & 14 HST & $21 \mathrm{HST}$ & 7 HST & $14 \mathrm{HST}$ & $21 \mathrm{HST}$ & \\
\hline Tested Liquid fertilizer & $13.25^{\mathrm{a}}$ & $20.21^{\mathrm{a}}$ & $31.12^{\mathrm{a}}$ & $4.40^{\mathrm{a}}$ & $5.73^{\mathrm{a}}$ & $7.33^{\mathrm{a}}$ & $4675.00^{\mathrm{a}}$ \\
\hline Comparable fertilizer & $15.78^{\mathrm{b}}$ & $23.16^{\mathrm{b}}$ & $35.96^{\mathrm{b}}$ & $4.15^{\mathrm{a}}$ & $6.20^{\mathrm{a}}$ & $7.20^{\mathrm{a}}$ & $5162.30^{\mathrm{b}}$ \\
\hline
\end{tabular}

Different superscripts in the same column shows significantly different $(\mathrm{P}<0.05)$; HST : days after planted 
Table 4. Characteristics of Liquid Fertilizer Made from Liquid Waste of Chicken Slaughterhouse and Comparable Fertilizer

\begin{tabular}{lcc}
\hline \multicolumn{1}{c}{ Contents } & Tested Fertilizer & Comparable fertilizer \\
\hline Lactobacillus sp. & $2.0 \times 10^{8}$ & $8.7 \times 10^{6}$ \\
Phosphate solvent & $2.7 \times 10^{3}$ & $7.5 \times 10^{6}$ \\
Yeast & $3.5 \times 10^{2}$ & $8.5 \times 10^{6}$ \\
Actinomycetes & - & + \\
Photosintetic Bacteria & - & + \\
pH & 4.50 & 3.90 \\
C-organic (ppm) & 14.43 & 27.05 \\
Nitrogen (ppm) & 9,2000 & 0.07 \\
Phosphor (ppm) & 143,000 & 3.22 \\
Potassium (ppm) & 600 & 7.67 \\
Calcium (ppm) & 0.26 & 1.67 \\
Magnesium (ppm) & 156.00 & 597.00 \\
Iron (ppm) & 2.23 & 5.54 \\
Manganese (ppm) & 0.79 & 3.29 \\
\hline
\end{tabular}

waste that is free from contamination of soil borne pathogens.

\section{Plant Response}

The effectiveness of fertilizer made from fermented liquid waste of chicken slaughterhouse markedly lower than the similar organic fertilizer (EM4) that has been widely circulated in the market (Table 3). This was seen clearly from the variables plant height at each observation time and also the fresh weight yield. The test results can be understood as the total nutrient content as well as the types of microbes present in the fermented fertilizer was lower than the EM4 (Table 4). However, these problems can be overcome through the enrichment process of fermentation, fermenting them using nutrient-rich organic matter and microbial functional enrichment as reported by Criolo et al. (2011).

\section{CONCLUSIONS}

The aerobic fermentation system combined with inoculation of the decomposer microbes (Lactobacillus spp.) and the addition 20\% (v/v) of a carbon source was the most appropriate method of fermentation in the production of liquid organic fertilizers made from liquid waste of chicken slaughterhouse. However, concerning the quality of the fertilizer which is based on physical, chemical and biological characteristic, and crop response still less than the similar commercial fertilizer (EM4). Nevertheless, the nitrogen and phosphor contents in this liquid fertilizer were significantly higher than those in the EM4. Therefore, the enrichment process using organic substances fermentation and microbial functional are suggested to improve the quality and effectiveness of the developed fertilizer.

\section{ACKNOWLEDGEMENTS}

Authors are grateful to the Ministry of Agriculture Indonesia for their financial support. We also thank to the staff of the Provincial Office of Maritime and Agriculture of Jakarta, for their help during the fieldwork.

\section{REFERENCES}

Anastassiadis, S. 2007. L-Lysine fermentation. Recent Patents on Biotechnology 1: 11-24.

Adrizal. 2009. Limbah peternakan unggas, isu dan penanganannya. http:// www.poultryindone 
sia.com. Accessed on 16 November 2013.

Ali, S., Ikram-ul-Haq, M.A. Qadeer and J. Iqbal, 2002. Production of citric acid by Aspergillus niger using cane molasses in a stirred fermentor. Elect. J. Biotech. 5: 114125.

Arifin, T. 2004. Pemanfaatan Limbah Bulu Ayam Potong Metode Pengukusan Untuk Ransum Ayam Potong. Tesis. Program Studi Pengelolaan Sumberdaya Alam dan Lingkungan. Universitas Sumatera Utara. Medan.

Bonsmira, M. and B. Jiang. 2011. Organic acids formation during the production of a novel peanut-milk kefir beverage. Br. J. Dairy Sci. 2(1):18-22.

Borja, R., F. Raposo, and B. Rincon. 2006. Treatment technologies of liquid and solid wastes from two-phase olive oil mills. Grasas Y Aceites. 57(1):32-46.

Burkepile, D. E., J. D. Parker, C. B. Woodson, H. J. Mills, J. Kubanek, P. A. Sobecky and M. E. Hay. 2006. Chemically mediated competition between microbes and animals: Microbes as consumers in food webs. Ecology. 87(11): 2821-2831.

Chojnacka, K., M. Baranska, H. Gorecka and H. Gorecki, 2006. Utilization of animal bones, feather and wood ash in the making of mineral fertilizers. Przem. Chem. 85/8-9: 1256-1259.

Coleman, M. E., M. L. Tamplin, J. G. Philips and B. S. Marmer. 2003. Influence of agitation, inoculum density, $\mathrm{pH}$, and strain on the growth parameters of Eschericia coli O157:H7-relevance to risk assessment. Int. J. Food Microbiol. 83: 147-160.

Criollo, H., T Lagos, E. Piarpuezan and R. Perez. 2011. The effect of three liquid bio-fertilizers in the production of lettuce (Lactuca sativa L.) and cabbage (Brassica oleracea L. var. capitata). Agronomía Colombiana 29(3): 415-421.

Cusack, D. F., W. L. Silver, M. S. Torn, S. D. Burton, and M. K. Firestone. 2011. Changes in microbial community characteristics and soil organic matter with nitrogen additions in two tropical forests. Ecology. 92(3):621-632.

Hoorman, J. J. and R. Islam. 2010. Understanding soils microbes and nutrient recycling. Agriculture and Natural Resources. SAG-1610. The Ohio State University.
Karthikeyan A. and N. Sivakumar. 2010. Citric acid production by Koji fermentation using banana peel as a novel substrate. Bioresource Tech. 101(14): 5552-5556.

Kim, K. J. 2011. Cost-effectiveness of converting fish waste into liquid fertilizer. Fish Aquat Sci 14(3):230-233.

Kivela, J. Helenius and A. Kangas. 2009. Meat and bone meal as fertilizer for oats from slaughter house waste to fertilizer. NJF Seminar 422. Fostering healthy food systems through organic agriculture. Focus on Nordic-Baltic Region. Tartu, Estonia, August 25-27, 2009. Pp. 55-56.

Leon, R.S., A.A.R. Carias and H.S. Anadon. 2009. Composting organic wastes from a commercial Slaughter house in Puerto Rico. Department of Animal Industry, University of Puerto Rico at Mayagüez. Puerto Rico.

Nakasaki, K., K. Nag and S. Karita. 2005. Microbial succession associated with organicmatter decomposition during thermopile composting of organic waste. Waste Manage. Res. 23: 48-56.

Okanovic, D., M. Ristic, S. Kormanjos, S. Filipovic and B. Zivkovcć. 2009. Chemical characteristics of Poultry slaughterhouse byproducts. Biotech. Anim. Husbandry 25 (1-2):143-152.

Prado, F. C., L. P. S. Vandenberghe, A. L. Woiciechowski, J. A. Rodrigues-Leon and C. R. Soccol. 2005. Citric acid production by solid state fermentation on a semi-piloy scale using different percentage treated cassava bagasse. Brazilian J. Chem. Eng. 22 (4):547555.

Sastro Y., D. Widianto, and J. Shiediq. 2006. Sekresi asam-asam organic oleh Aspergillus niger YD 17 yang ditumbuhkan dengan batuan fosfat. J. Biota XI (3):167-175.

Sastro, Y. and I.P. Lestari. 2011. The growth and yield of sweet corn fertilized by dairy cattle effluents without chemical fertilizers in Inceptisols. J. Trop. Soils. 16(2):140-143.

Tronina, P., and F. Bubel. 2008. Production of organic fertilizer from poultry feather wastes excluding the composting process. Polish J. Chem. Tech. 10(2): 33-36.

Tsai, S., C. Liu and S. Yang. 2007. Microbial conversion of food wastes for biofertilizer production with thermophilic lipolytic microbes. Renewable Energy. 32(6):904-915 